\title{
AN-NIDA THEORY ACCORDING TO THE PERSPECTIVE OF NAHWU SIBAWAYH THOUGHT
}

\author{
Vania Cahyaningtyas \\ Universitas Islam Negeri Sunan Kalijaga (UIN SUKA) Yogyakarta \\ vaniacahyaningtyas65@gmail.com
}

\begin{abstract}
The nahwu study cannot be separated from an important figure named Sibawayh. He is a scholarly figure who has been consensually recognized for this superiority and scientific genius, he is recommended as a reference for other scholars, especially when it comes to discussing knowledge about Arabic grammar in accordance with the rules. Although he was a native Persian who was not very good at conversing Arabic, he was a very influential expert on Arabic grammar. His effort entitled al-Kitab is the first recorded book of Arabic grammar. He has been recognized as one of the greateast linguists of all the time especially in the filed of nahwu among linguists in the world. Sibawayh contributed his thoughts about nahwu to several types in an-nida and munada according to his version. The research method used in writing this journal is a qualitative descriptive method, the writer describes munada and its types.
\end{abstract}

keywords : Sibawayh, An-Nida, Munada, Nahwu, al-Kitab.

\section{Introduction}

The fullname of a Persian Proponent of nahwu science is Abu Bisyr 'Amr ibn 'Utsman ibn Qanbaral-Harits, better known as Sibawayh. He was born in the al-Bayda' area, near the city of Siraz, where he died. His youth spent in Basrah. His initial interestwas in the study of Hadith dan fiqh. Than he was interested in studying Arabic grammar. ${ }^{1}$

Sibawayh is an honorary nickname (laqab) for the great ulama 'nahwu mazhab Basrah. The word "sîbawaih" (سيبويه) comes from Persian (Iran) which consists of two words, namely : سيبـ which means apple and ويه wheans aroma. So, Sibawayh means the aroma of apples. In addition, some argue that sîbawaih comes from the word سي which means thirty, wي ويه which means the smell of fragrance; thus it means thirty fragrant smells. This title is indeed related to the

\footnotetext{
${ }^{1}$ Ahmad Najib Afandi, Madrasah Nahwu Bashrah Dan Kufah. (Kediri: Sumenang, 2004).
} available at: http://journal.uir.ac.id/index.php/THUMUHAT 6 
fragrance of his name as a character who managed to systematically compile nahwu's work and his work was sufficient to determine the development of nahwu in the following years. ${ }^{2}$

Sibawayh received wide attention from linguists and history of Arabic language, especially from historians of Islamic literature in general, both in the West and in the East. Broadly speaking, the attention of these experts revolves around biography, the contribution of Sibawayh's grammatical thought to Arabic grammar, the reaction of the first generation of nahwu experts to Sibawayh's thought, the position of Sibawayh's grammatical thought in the middle of the grammar school that was developing at that time, Sibawayhi's masterpiece, the al-Kitab, manuscripts and the originality of their thoughts. ${ }^{3}$

Sibawayh is considered one of the important first Arabic scholars. He is the author of the first book published in Arabic : Sibawayh's Kitab in which he garhered the rules of Arabic in its four levels : Linguistics, Syntax, Morphology, dan Phonetics. This book was soon considered the cornerstone from which all other later grammarians throughout the years based their studies pn. Grammarians quoted from it, tried to explain its complex matters and extract from it syntatic rules to justify their publications.

This matter urged us to think seriously of the way other grammarians treated Sibawayh's grammar, whether quoting or understanding, in about 80 syntatic publications starting with AlMuktadhab by Al-Mubarid (280) and end up with Hasnia Al-Khudary Ala Shareh Ibn Akeedl $(1287 \mathrm{H})$. This study came to explicate all viewpoints to investigate and scrutinize what is wrongly related to sibawayh and asses them. ${ }^{4}$

The nahwu study cannot be separated from an important figure named Sibawayh. Although not an Arab, but from a Persian who is not very good at conversing in Arabic, this character often becomes an icon or symbol of nahwu. There has not been a book that has been properly compiled, either before or after his time, although some scholars consider his work, al Kitab, to be a compilation of "learning results" to al-Khalil ibn Ahmad, rather than an original work of creative thinking. ${ }^{5}$

\footnotetext{
${ }^{2}$ Mazîd Ismâ‘îl Na ‘îm, Sîbawaih Al-Bashrî., Cet. I (Damaskus: Dâr Ibn Katsîr, 1999).

${ }^{3}$ Muhammad Haroun. Abdussalam, Sibawayh Abi Bishr Amr Ibn Uthman Ibn Qanbar., Cet. II, 1968 (Kairo: Rumah Penulis Arab untuk Percetakan dan Penerbitan, 1968).

${ }^{4}$ Mazin Abdulrasoul Salman, Sibawayh's Grammar in Grammarians 'Books An Analytic and Evaluative Study (Baghdad, Iraq: To the council of the college of Education Al- Mustansiriyah University . In a partial fulfillment Of the Doctoral degree of Arts in Arabic language \& Linguistics, 2006), 2.

${ }^{5}$ Sîbawaih, Al-Kitâb. Ditahqî̀ 'Abd al-Salâm Muhammad Hârûn. (Kairo: Dâr al-Qalam, 1966).
} 
$\mathrm{He}$ is a very influential expert on Arabic grammar. His work, entitled al-Kitab, is the first recorded book of Arabic grammar. He has been recognized as the greatest expert on Arabic language and is considered one of the greatest linguists of all time among the linguists of the world. ${ }^{6}$

His first lessons in religious knowledge were at Shiraz. He moved to Basrah when he was a teenager. In this city, he later joined various forums for experts in fiqh and hadith. He also followed diligently in the science council that was brought up by Hammad ibn Salamah ibn Dinar (d. $169 \mathrm{H}$ ), a famous hadith scholar at that time. It is reported that Sibawayh made several mistakes (lahn) in reciting the hadith of the Prophet, so that he was motivated to deepen the Arabic language and its grammar. He then joined the forum (halaqah) of linguists and nahwu experts, such as: 'Isa ibn' Umar ats-Tsaqafi (d. $149 \mathrm{H}$ ), Abu al-Khaththab al-Akhfasy (al-Akhfasy senior), Yunus ibn Habib al- Dhabbi (d. 182 H), Ab-Zaid al-Ansari, author of al-Nawâdir fi al-Lughah, Harun ibn Musa alNahwi (d. $170 \mathrm{H}$ ), expert Qira'at, and studied specifically from al-Khalil ibn Ahmad (d. $166 \mathrm{H}$ or $175 \mathrm{H})^{7}$

From this last teacher, he obtained almost all the lessons of nahwu and harf, both through his request for dictation (istimla ') and through his own mutilation. With these two methods, and reinforced by the question and answer method and asking for a more detailed explanation directly from his teacher (istifsâr), Sibawayh strengthened his knowledge and understanding of Arabic linguistics and nahwu. Apart from that, he was also diligent in memorizing the arguments and proofs (martyrs) that were narrated from the Arabs through his teacher. Like the teacher, he too often conducted a "direct survey" into the interior of Baduwi on the land of the Hejaz Arabia in general and make field notes to gain knowledge of the language still original and not contaminated with errors in Arabic. ${ }^{8}$

\section{An-Nida' According to Sibawayh's Thought}

There are 2 types of Munada 'according to Sibawayh :

a) Maf'uulun Bih

\section{Example :}

\footnotetext{
${ }^{6}$ Mâzin al-Mubârak, Maqâlât Fi Al- 'Arabiyyah, Cet. I (Damaskus: Dâr al-Bas yâ'ir, 1999).

${ }^{7}$ Tammâm Hassân, Al-Ushûl : Dirâsah Epistimûlûjiyyah Li al-Fikral-Lughawî̀'Inda al-'Arab : Al-Nahwu - Fiqh alLughah-al-Balâghah, Edisi Revisi (Kairo: 'Âlamal-Kutub, 2000).

8 Muhbib, . “. 'Mengenal Pemikiran Nahwu Sibawayh (148-180 H/765-796 M)'.,” June 5, 2017, https://fitk.uinjkt.ac.id/mengenal-pemikiran-nahwu-sibawayh-148-180-h765-796-m/.
} 


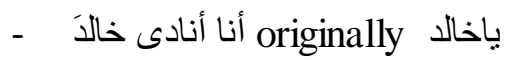

- يازينب أنا أنادى زينب

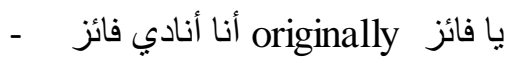

b) Mukhotob : Marfu '

Example :

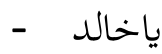

-

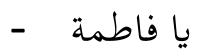

-

- 9

Here are 8 types of an-Nida 'according to Sibawayh :

a) Must be Marfu 'and Mufrod (mandatory)

Example :

- يا خالد الطويلٌ

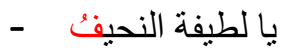

b) Representing Words of Praise and Words of Reproach

Not just racing on Kholid and here are the words of praise. But the race against two people, Rojulu and Abdallah. Those whose harakat "د" is in the community of nashb because there is a'athof 'الصسلمَيَنِ" have a fathah society because they match the closest word, namely from the word Abdallah who has fathah society.

Example :

- ميأيها الرجُجل وعبدَ الله المسلمَبنِ الصالحَينِ

c) Issues and Traits at One Level

${ }^{9}$ Omar Abdul Jabbar, Arbaeen Al-Nawiyyah (Riyadh: Kantor Kerjas ama untuk Penyebaran dan Kesadaran Masyarakat, 2001). 
Example :

- مبازيدَ ابنَ عَمرُ

- يا محمدَ حبيَب الله

d) Isim which is repeated in the state of Idhofah. The First Word Is Just Like The Second Word

Example :

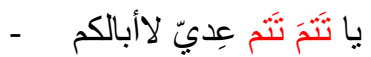

(yaa Taima Taima from the lineage of 'Adi you are an orphan)

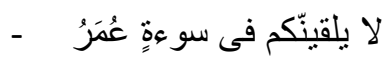

(Don't let Umar meet you in a bad condition).

e) Idhofah Mentioning Who Was Called for Himself

Example :

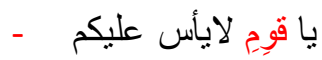

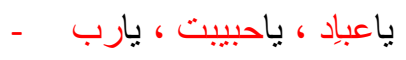

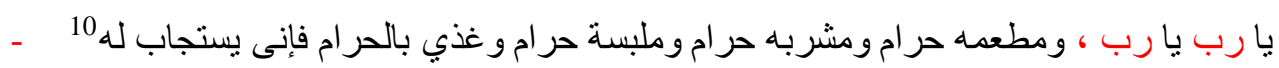

Especially for an-Nida 'ي" is omitted, because an-Nida' is often called the Arab is replaced Kasroh.

f) Two Types of Isim which are combined into One Meaning Mudhof has several more types including munada' mudhof. Namely munada in the form of a pure isim (final shohih) which is translated as ya 'mutakallim persists the letter ya'inatu word based on the original word with mengukunkan.

Example :

بيتُ الله

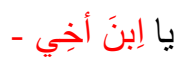

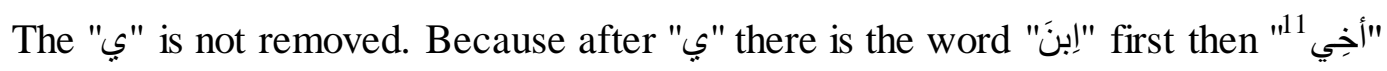

10 عمر عبد الجبار, عمر عبد الجبار (Riyadh: المكتب التعاون للاعوة وتو عية الجاليات بالربوة n.d.), 35.

${ }^{11}$ Ahmad Mukhtar Umar, Al-Bahts al-Lughawi 'Inda al- 'ArabMa'a DirâsatLi Qadhiyyatat-Ta'Tsîr Wa at-Ta'atstsur, Cet. VIII (Kairo: Âlam al-Kutub, 2003). 
g) Nida 'which is given to Munada (who is called) with the letters Idhofah in Dua Situation Istighotsah (asking for help) and Ta'ajjub (surprising).

- Istighotsah

Example:

- يَا للنََّسِ

(ask for help)

The word cannot be interpreted textually. Harakat fathah in the letter "ل show istighotsah. And the vowel of kasroh in the letter "w" indicates idhofah. ${ }^{12}$

- $\quad$ Ta'jub

Example :

- يَا للْعَجَب

h) Isim which is preceded by a kasroh Isim which is preceded by a kasroh is an order for the person who is called.

\section{Example :}

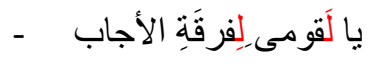

: J j people who ask to help him

: who need to be helped ${ }^{13}$

In his treatment of defiteness (KitabI, 219-226/187-193) 7, Sibawayh argues that a distinction of the five definite classes, i.e., proper nouns, the mudaf annexed to the definite when the speaker does not intend the meaning of tanwin, the definite article alif-lam, vague nouns and pronouns (kitab I, 219/187), is based on a kind of hirearchy of definiteness. However, words are either definite or indefinite, they cannot possibly be more or less definite. Conversely, words can be more or less identifiable and the crucial element here is the listener's ability to identify a particular referent is nakira not when it is grammatically coded as such but rather when the listener fails to recognise it as knpwn or familiar. The hierarchical order in Sibawayh relates more precisely the syntatic behaviour

عبد السلام محمد هارون, الكتاب كتاب سييوية أبي بشر عمرو بن عثمان بن قنبر, الجزء الثانى (القاهرة: دار الكاتب العربي للطباعة و النشر, 1968), 12 $219-182$.

$$
13 \text { الدكتور عبده الر اجي، ـ درس في المز اهب النحوية، (الاسكندرية و بيروت العربية : دار النهضة العربية)، } 34 \text { - } 11 \text { النية. }
$$


and degree of adjectival qualifiability of each definite class to its corresponding definite nature. Moreover, the rule of definiteness and the pragmayic principle of identifiabilty have a major role in determining word order in Arabic nominal sentences as well as the eligibility of nouns and verbs to occupy the initial position in nomina; sentences. ${ }^{14}$

\section{Methods}

The research method used in writing this journal is a qualitative descriptive method, namely the author describes and explains about munada and its types. In line with what is expressed by Cresswell in his book Educational Research that qualitative research is a type of research in which the researcher is very dependent on information from the object/participant on : a wide scope, general questions, data collection which mostly consists of words/texts from participants, explain and analyze words to conduct reserach subjectively.

\section{Result and Discussion}

\section{Thought Contribution of Nahwu Imam Sībawaih}

Imam Sỉbawaih has the real name 'Amrun bin' Utsmān bin Qanbar Abū Bisyr. The word "Sibawaih" is a nickname that comes from Persian, the word "sib" means apple, while "waih" it means fragrant. So the word "Sibawaih" means the fragrance of apples. It is said that the fragrance of the apple emanated from his body. Imam Sibawaih was born in Persia in $148 \mathrm{H}-180 \mathrm{H}$ or in 765 AD-795 AD, to be precise in the city of Albaidha, 8 one of the cities in the Istikhar Province of the Persian state (Iran, now) near Syairaz. Sỉbawaih and his family moved to the city of Basra, the country of Iraq, where he grew up in a scientific environment.9 Since childhood he studied with scholars from the schools of Basra, Hijaz, Najd (Nejed), Tuhamah and other cities. And when he performed the pilgrimage, he had studied with the scholars he met in Haramain, so he was included in the knowledge of qiyās (analogies) and qirā'at. ${ }^{15}$

The Sibawaih Book provides a major scientific contribution, especially in the study of Arabic Syntax, the role of Imam Sibawaih which is widespread, giving birth to modern nahwu figures, said Syauqi Dhaif who has explained that anyone who reads this phenomenal work of Sibawaih will be more stable because this book is the mother book of nahwu and the arrangement also that the role of

\footnotetext{
${ }^{14}$ Amal Magory, "Kitāb Sībawayhi and Modern Linguistics. A Synoptic View of a Complementary Relationship," University of Cambridge, Synergies Monde arabe ${ }^{\circ} 7$ - 2010 pp. 29-34, 2010, 32.

${ }^{15}$ Ahmad Najid Afandi, Madrasah Nahwu Bashrah dan Kufah (kediri: Sumenang, 2004), 24.
} 
the teacher, namely Imam Khalil bin Aḥmad taught Sỉbawaih a lot about the basics of 'àmil theory and its laws and it is necessary to know that the theory of' amil theory is actually from the teacher's thought. ${ }^{16}$

Some of Imam Sibawaih's contributions in the development of nahwu science, including :

1) The method of nahwu science which was initiated with patience by Imam Sibawaih as a form of contribution, made the Al-Qur'an the main reference because the language of the Al Qur'an came down with Arabic which was very fasāḥah or fuṣḥa.

2) The work of Sỉbawaih (Al-kitāb) has become a measure of the importance of nahwu science from the classical to the modern period.

3) Imam Sibawaih did not make ma'nawi hadith as the basis for his method of studying nahwu science because the people of 'ajam were not fluent.

4) Imam Sibawaih made Arabic poetry as one of the main references with a very strict selection.

5) Imam Sỉbawaih made the hadith lafại a language that was considered fluent in the nahwu science method because his language was not influenced or mixed by foreign languages. ${ }^{17}$

\section{Conclusion}

Sibawayh's thinking is very genius about everything about nahwu (grammatical grammar). He is a very influential linguist. There has not been a book that has been properly compiled, either before or after his time, although some scholars evaluated his work, the al-Kitab, more as a compilation of "learned results" of al-Khalil ibn Ahmad, rather than original works of creative thinking. I will here express his thoughts on one of his works, namely in chapter an-Nida, which includes several types :

- Must be marfu 'and mufrod (mandatory).

- Include words of praise and reproach.

- Isim and Traits at One Level.

- Isim who is repeated in Idhofah state. The first word is exactly like the second word.

- Idhofah Mentioning Who Was Called for Himself.

- Two types of isim which are combined into one meaning.

\footnotetext{
${ }^{16}$ Moh. Pribadi, "Sumbangan Al-KhalilDalam Perkembangan Nahwu Arab," Adabiyyat : Jurnal Bahasa Dan Sastra Vol.1, No.1 (June 2017): 89.

${ }^{17}$ Holilulloh, Andi, “'Kontribusi Pemikiran Nahwu Imam Sỉbawaih Dan Ibrāhīm Muṣṭafā Dalam Linguistik Arab (Studi Komparatif Epistemologis).," Alfaz (Arabic Literatures for Academic Zealots) Vol. 8 No.1, June 2020 |ISSN: 2339-2882, E-ISSN: 2620-5351 (n.d.): 51-52.
} 
- Nida 'which is idolized to Munada (who is summoned) with the letters idhofah in two situations istighotsah (asking for help) and Ta'ajjub (surprising).

- Isim which is preceded by lam kasroh.

Suggestions for further research, the writer hopes that the research on the next of An-Nida Theory According To The Perspective Of Nahwu Sibawayh Thought can be continued into the next research considering that there are still many values contained in the next of An-Nida Theory According To The Perspective Of Nahwu Sibawayh Thought. Both in terms use of other theoretical studies, the way understanding Sibawayh in later syntatic heritage, and others.

\section{References}

Ahmad Mukhtar Umar. Al-Bahts al-Lughawi 'Inda al-'Arab Ma'a Dirâsat Li Qadhiyyat at-Ta'Tsîr Wa at-Ta'atstsur. Cet. VIII. Kairo : Âlam al-Kutub, 2003.

Ahmad Najib Afandi. Madrasah Nahwu Bashrah Dan Kufah. Kediri : Sumenang, 2004.

Amal Magory. Kitāb Sỉbawayhi and Modern Linguistics. A Synoptic View of a Complementary Relationship. University of Cambridge, Synergies Monde arabe n 7 - 2010 pp. 29-34, 2010, 32.

Holilulloh, Andi. Kontribusi Pemikiran Nahwu Imam Sībawaih Dan Ibrāhīm Mușṭafā Dalam Linguistik Arab (Studi Komparatif Epistemologis). Alfaz (Arabic Literatures for Academic Zealots) Vol. 8 No.1, June 2020 | ISSN: 2339-2882, E-ISSN: 2620-5351 (n.d.): 51-52.

Mazîd Ismâ‘îl Na‘îm. Sỉbawaih Al-Bashrî. Cet. I. Damaskus: Dâr Ibn Katsîr, 1999.

Mazin Abdulrasoul Salman. Sibawayh's Grammar in Grammarians Books An Analytic and Evaluative Study. Baghdad, Iraq : To the council of the college of Education Al- Mustansiriyah University . In a partial fulfillment Of the Doctoral degree of Arts in Arabic language \& Linguistics, 2006.

Mâzin al-Mubârak. Maqâlât Fi Al-‘Arabiyyah. Cet. I. Damaskus : Dâr al-Basyâ’ir, 1999.

Moh. Pribadi. Sumbangan Al-Khalil Dalam Perkembangan Nahwu Arab. Adabiyyat: Jurnal Bahasa Dan Sastra Vol.1, No.1 (June 2017).

Muhammad Haroun. Abdussalam. Sibawayh Abi Bishr Amr Ibn Uthman Ibn Qanbar. Cet. II, 1968. Kairo: Rumah Penulis Arab untuk Percetakan dan Penerbitan, 1968. 
Muhbib. Mengenal Pemikiran Nahwu Sibawayh (148-180 H/765-796 M). June 5, 2017. https://fitk.uinjkt.ac.id/mengenal-pemikiran-nahwu-sibawayh-148-180-h765-796-m/.

Omar Abdul Jabbar. Arbaeen Al-Nawiyyah. Riyadh : Kantor Kerjasama untuk Penyebaran dan Kesadaran Masyarakat, 2001.

Sîbawaih. Al-Kitâb. Ditahqîq ‘Abd al-Salâm Muhammad Hârûn. Kairo: Dâr al-Qalam, 1966.

Tammâm Hassân. Al-Ushûl: Dirâsah Epistimûlûjiyyah Li al-Fikr al-Lughawî 'Inda al-'Arab : AlNahwu - Fiqh al-Lughah - al-Balâghah. Edisi Revisi. Kairo: 'Âlam al-Kutub, 2000.

عبد السلام محمد هارون. الكتاب كتاب سبيويه أبي بشر عمرو بن عثمان بن قنبر . الجزء الثانى. القاهرة: دار الكاتب العربي ا تلطباعة و النشر, 1968.

. عمر عبد الجبار. عمر عبد الجبار. Riyadh: المكتب التعاون للاعوة وتوعية الجاليات بالربوة, n.d. 